Mr. M. H. Donald a large collection of fossil invertebrates, formed by the late Mrs. J. Longstaff, chiefly from the Carboniferous of Great Britain, and including more than 20 figured specimens. The Mineral Department has received by gift from Prof. E. D. Mountain a specimen of boksputite, a species new to the collection ; from Dr. E. S. Simpson distorted crystals of cassiterite from Pilbara goldfield; and from Mr. R. Murray-Hughes a series of rocks collected by him on the Aberdare Range, Kenya Colony, in 1933. A piece, weighing $99 \mathrm{gm}$, of the meteoric stone which fell on May 26, 1932, at Kuznetzovo, Tatarsk district, Siberia, has been acquired by exchange.

AMONG recent acquisitions of the Department of Botany is a complete collection of the observed phanerogamic flora of Etah (Inglefield Land, northwest Greenland) made by Dr. G. N. Humphreys on the Oxford University Ellesmere Land Expedition. A few gatherings from the Disco area of west Greenland are included, but none from Ellesmere Land, as the Expedition left there before the collecting season. The material, of about three hundred numbers, is well collected and dried, and is a valuable addition to those already in the Museum from these high altitudes in Greenland. Another addition comprises 122 sheets of Finnish plants collected by Mr. H. Krogerus, who accompanied Mr. G. J. Kerrich on his recent expedition. The plants are all critical species, and correspond to a list supplied by the Department. They were named in Finland, and thus have an additional value. Collections from Mozambique, Angola and Tanganyika have also been received. Miss G. Lister has presented the simple microscope and stand of her grandfather (Joseph Jackson Lister) to the Department. This he used "when he was in the full swing of work". It was constructed before or about 1820. J. J. Lister (1786-1869) was "the discoverer of the principle upon which the modern microscope is constructed" ("Dictionary of National Biography").

\section{New Meteorological Observatory at Brisbane}

THE formal opening of Crohamhurst Observatory, situated in lat. $26^{\circ} 50^{\prime} \mathrm{S}$., long. $152^{\circ} 55^{\prime} \mathrm{E}$., by H. E. the Governor of Queensland took place on August 13, 1935. The observatory will be concerned with meteorological and solar work, and will in particular attempt seasonal forecasting on the basis of the sunspot cycle. The City of Brisbane is visited by disastrous floods about every twenty years, and the rainfall which is received in the valley in which the new Observatory is situated is the sole cause of these floods; in fact, the record rainfall of Australia, $35 \cdot 7$ inches in 24 hours, was recorded at Crohamhurst in 1893. The director of the new observatory is Mr. Inigo Jones, who has been engaged on meteorological work in this part of Australia for forty years, and claims an accuracy of more than eighty per cent in forecasting weather conditions. His views on the relation of weather to the sunspot cycle and to the movements of the planets have been referred to from time to time in our columns (see NAture, July 2, 1932, p. 31, and Sept. 2, 1933, p. 345). Brisbane is to be congratulated on the possession of its new observatory.

\section{Geological Survey and Museum}

From the opening of the Geological Museum at South Kensington on July 3 until December 3I, 159,000 visitors passed through its doors. This compares with an average total of 18,000-20,000 a year at the old museum in Jermyn Street. Recent additions and presentations to the Museum include a fine collection of cut zircons, one royal blue stone of 44 carats, being unique in size and colour ; a collection of multi-coloured doubly-terminated tourmaline crystals from Mesa Grande, California; a large composite photograph of the moon from the Mount Wilson Observatory, and other series of enlarged photographs of earthquakes and other geological phenomena; more than two thousand British building stones and other collections illustrating economic geology, bequeathed by Mr. B. E. LainePearson; and some 250 rocks recently collected for the Museum from southern Norway.

\section{Sunspots during 1935}

A PRovisional value of the mean daily area of sunspots for 1935 is 550 millionths of the sun's hemisphere. This may be compared with 119 millionths for the year 1934 and 88 millionths for 1933, the date of the last minimum of the 11-year cycle being 1933.8. During 1935, solar activity - as shown by the occurrence of sunspots, disk markings in hydrogen and calcium light, and prominences at the limb-increased to a marked degree, especially during the latter half of the year. The maximum of the cycle, which normally occurs about four years after the preceding minimum, may be expected in 1937-38, but the epochs of the cycle are not amenable, as is well known, to exact prediction.

\section{Recent Large Sunspots}

Since the beginning of last December, when a very large group of sunspots crossed the sun's disk, there have been other groups of lesser magnitude but nevertheless of considerable extent, especially the group most recently visible. These groups are summarised as follows, the area being expressed in millionths of the sun's hemisphere. It may be noted that a single spot of area 500 units, when near the centre of the disk so as to escape foreshortening, is usually visible to the naked eye. Times are in U.T.

$\begin{array}{lccc} & \text { Central Meridian } & & \text { Maximum } \\ \text { Date on Disk } & \text { Passage } & \text { Latitude } & \text { Area } \\ \text { Dec. 6-19 } & \text { Dec. } 12.5 & 23^{\circ} \mathrm{S} . & 900 \\ \text { Dec. 28-Jan. 9 } & \text { Jan. } 3.4 & 12^{\circ} \mathrm{S} . & 900 \\ \text { Jan. 1-14 } & \text { Jan. } 7.8 & 27^{\circ} \mathrm{N} . & 1100 \\ \text { Jan. 14-26 } & \text { Jan. 19.9 } & 32^{\circ} \mathrm{S} . & 1800\end{array}$

No magnetic storms were recorded at Greenwich (Abinger Station) on or about the time of central meridian passage of any of the above spots, but from Jan. $8^{\text {h. }} 4^{\text {d. }}$ for three or four days the traces appear distinctly unsteady. On Jan. 24d. 17h., however, another disturbance commeneed ; but this 